\title{
Flavobacterium lindanitolerans sp. nov., isolated from hexachlorocyclohexane-contaminated soil
}

\author{
Simran Jit, Mandeep Dadhwal, Om Prakash and Rup Lal \\ Molecular Biology Laboratory, Department of Zoology, University of Delhi, Delhi 110 007, India
}

Correspondence

Rup Lal

duzdel@vsnl.com

\begin{abstract}
A Gram-negative, non-spore-forming, cream-yellow-pigmented bacterial strain, IP-10 ${ }^{\top}$, was isolated from soil samples from a waste site highly contaminated with hexachlorocyclohexane in Ummari village, India. The organism showed the highest 16S rRNA gene sequence similarity of $92.7 \%$ with Flavobacterium soli KCTC $12542^{\top}$ and levels of $87-92 \%$ with the type strains of other recognized species of the genus Flavobacterium. The DNA G $+\mathrm{C}$ content of strain IP-10 ${ }^{\top}$ was $31 \mathrm{~mol} \%$. The predominant fatty acids were iso- $\mathrm{C}_{15: 0}(22.1 \%)$, iso- $\mathrm{C}_{17: 0} 3-\mathrm{OH}(18.5 \%)$ and summed feature 3 (comprising $\mathrm{C}_{16: 1} \omega 7 \mathrm{c}$ and/or iso- $\mathrm{C}_{15: 0} 2-\mathrm{OH} ; 13.2 \%$ ). Strain IP-10 ${ }^{\top}$ could be differentiated from recognized species of the genus Flavobacterium based on a number of phenotypic features. Strain IP-10 $10^{\top}$ is therefore considered to represent a novel species of the genus Flavobacterium, for which the name Flavobacterium lindanitolerans sp. nov. is proposed. The type strain is $\mathrm{IP}^{-10^{\top}}$ (=MTCC $8597^{\top}=$ CCM $\left.7424^{\top}\right)$.
\end{abstract}

The genus Flavobacterium, the type genus of the family Flavobacteriaceae, was proposed by Bergey et al. (1923) and the description was considerably emended by Bernardet et al. (1996). It belongs to the phylum Bacteroidetes (Bernardet \& Bowman, 2006) (formerly the Flavobacterium-Flexibacter-Bacteroides group; Woese et al., 1990). Members of the genus are widely distributed in nature and are routinely isolated from soil (Yoon et al., 2006), sediments, freshwater and marine water ecosystems, microbial mats (Van Trappen et al., 2003, 2004), sea ice (Humphry et al., 2001) and infected fish. The genus Flavobacterium comprises Gram-negative, non-sporeforming, strictly aerobic, predominantly gliding, pigmented bacteria with menaquinone- 6 as the major respiratory quinone and a DNA $\mathrm{G}+\mathrm{C}$ content of $30-41 \mathrm{~mol} \%$ (Bernardet \& Bowman. 2006; Park et al., 2006). Flavobacterium aquatile is the type species of the genus.

The present study deals with the taxonomic characterization of a novel species of the genus Flavobacterium isolated from soil from a recently created waste site for a lindane manufacturing unit situated in Ummari village, Lucknow city, in the state of Uttar Pradesh, India. Lindane, $\gamma$-hexachlorocyclohexane $(\mathrm{HCH})$, is the only $\mathrm{HCH}$ isomer that has insecticidal properties. Strain IP- $10^{\mathrm{T}}$ was isolated after 7 days incubation at $28{ }^{\circ} \mathrm{C}$ by plating serially diluted

Abbreviations: FAME, fatty acid methyl ester; $\mathrm{HCH}$, hexachlorocyclohexane.

The GenBank/EMBL/DDBJ accession number for the 16S rRNA gene sequence of strain $\mathrm{IP}-10^{\top}$ is EF424395.

A phylogenetic tree obtained by using the EzTaxon server is available with the online version of this paper. soil samples on Luria-Bertani agar plates (10 g tryptone, 5 g yeast extract, $5 \mathrm{~g} \mathrm{NaCl}, 1 \mathrm{~g}$ D-glucose, $15 \mathrm{~g}$ agar per litre) containing nystatin $\left(30 \mu \mathrm{g} \mathrm{ml}^{-1}\right)$ and streptomycin $\left(200 \mu \mathrm{g} \mathrm{ml}^{-1}\right)$, used to isolate $\mathrm{HCH}$-degrading sphingomonads (Vanbroekhoven et al., 2004). 16S rRNA gene sequence analysis, fatty acid profiling and other phenotypic characteristics revealed that the new isolate belonged to the genus Flavobacterium but exhibited sufficient significant differences from other closely related members of the genus to be considered as representing a novel species.

16S rRNA gene sequence analysis was carried out as described by Prakash et al. (2007). Briefly, a single colony of strain IP $-10^{\mathrm{T}}$ was picked with a sterile toothpick, suspended in $50 \mu \mathrm{l}$ of sterile deionized water and heated at $95{ }^{\circ} \mathrm{C}$ for $10 \mathrm{~min}$. Following centrifugation at $9000 \mathrm{~g}$ for $5 \mathrm{~min}$ and ten-fold dilution with sterile deionized water, the 16S rRNA gene sequence was amplified by using the universal primer pair 27F (5'-AGAGTTTGATCCTGGCTCAG- $\left.3^{\prime}\right)$ and 1492R (5'-TACGGTTACCTTGTTACGACTT-3'). The amplified product was purified and used for cycle sequencing with BigDye terminator chemistry and run on a 3100 Avant Genetic Analyzer (Applied Biosystems).

The stretch of the 16S rRNA gene sequence obtained (1359 bp) was checked manually for quality and gaps. Similarity searches were conducted by using the Sequence Match tool of the Ribosomal Database Project (http:// rdp.cme.msu.edu/seqmatch/seqmatch_intro.jsp) and the BLAST program of the National Centre for Biotechnology Information (http://www.ncbi.nlm.nih.gov). For construction of phylogenetic trees, sequences of the 19 most closely 
related species of the genus Flavobacterium were selected from the RDP and NCBI databases. The 16S rRNA gene sequence of the type strain of Cellulophaga lytica was used as an outgroup and all the selected sequences were aligned via the CLUSTAL_X program (Thompson et al., 1997). Terminal nucleotides not common to all sequences were removed. Phylogenetic analysis was carried out by using the PHYLIP package, version 3.5c (Felsenstein, 1993), and TREeCON (Van de Peer \& De Wachter, 1994). The evolutionary distance matrix was calculated according to the distance model of Jukes \& Cantor (1969) and an evolutionary tree was constructed by using the neighbourjoining method of Saitou \& Nei (1987). The topology of the phylogenetic tree was statistically evaluated based on 100 resamplings by using the SEQBOOT and CONSENSE programs in the PHYLIP package and the bootstrap option in the TREECON program. Phylogenetic analysis was also performed with the parsimony method by using DNAPARS, including bootstrap analysis of 100 resamplings.

Strain IP- $10^{\mathrm{T}}$ showed highest $16 \mathrm{~S}$ rRNA gene sequence similarity of $92.7 \%$ with Flavobacterium soli KCTC $12542^{\mathrm{T}}$, and showed levels of similarity of $87-92 \%$ with the type strains of other recognized species of the genus Flavobacterium. Strain IP- $10^{\mathrm{T}}$ occupied a separate position in the neighbour-joining tree (Fig. 1) and formed a distinct cluster with Flavobacterium columnare ATCC $23463^{\mathrm{T}}$,
Flavobacterium terrae DSM $18829^{\mathrm{T}}$, Flavobacterium saliperosum CGMCC $1.3801^{\mathrm{T}}$, Flavobacterium suncheonense KACC $11423^{\mathrm{T}}$, Flavobacterium cucumis DSM $18830^{\mathrm{T}}$ and Flavobacterium croceum $\mathrm{EMB} 47^{\mathrm{T}}$. This grouping was clearer when the EzTaxon server (http://www.eztaxon. org/; Chun et al., 2007) was used to construct the tree (see Supplementary Fig. S1 in IJSEM Online). This topology was confirmed in the maximum-parsimony tree. Based on low levels of $16 \mathrm{~S}$ rRNA gene sequence similarity and phylogenetic analysis, it was concluded that strain IP $-10^{\mathrm{T}}$ represents a novel species of the genus Flavobacterium.

Fatty acid methyl ester (FAME) analysis was carried out at the Microbial Type Culture Collection (MTCC) division of the Institute of Microbial Technology, Chandigarh, India. For this purpose, strain IP- $10^{\mathrm{T}}$ was grown on trypticase soy agar (TSA) at $37^{\circ} \mathrm{C}$ for $22-24 \mathrm{~h}$. Extraction, saponification and methylation of fatty acids were carried out as described by Miller (1982) and Kuykendall et al. (1988). The mixture of FAMEs was separated on a gas chromatograph (Agilent 6890) equipped with flame-ionization detector. Identification of FAMEs was accomplished by using the Aerobe (TSBA50, version 5) database of the Sherlock Microbial Identification System (MIDI Inc.).

The major fatty acids of strain IP- $10^{\mathrm{T}}$ were iso- $\mathrm{C}_{15: 0}$ $(22.0 \%)$, iso- $\mathrm{C}_{17: 0} 3-\mathrm{OH}(18.5 \%)$ and summed feature 3

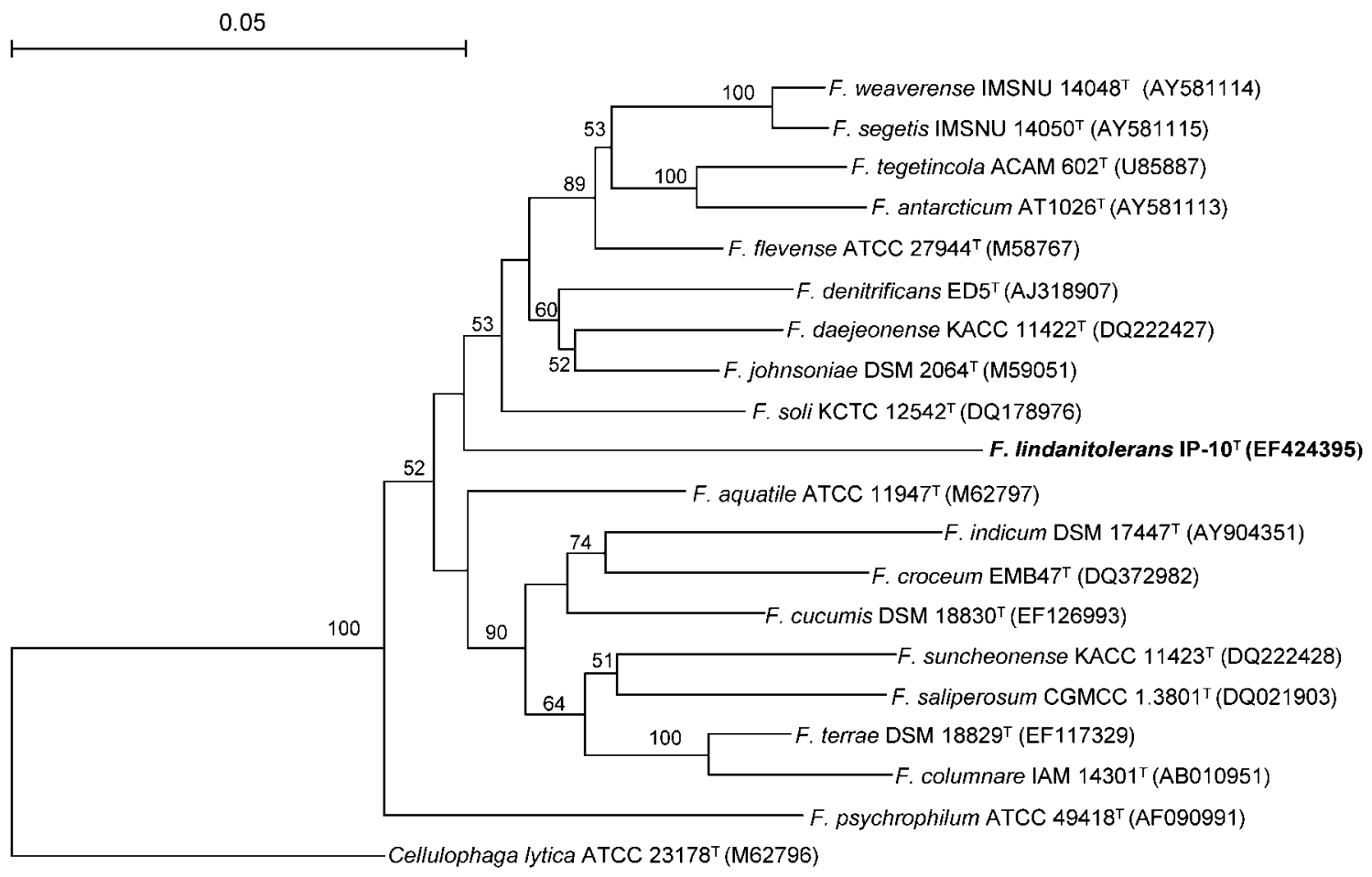

Fig. 1. Phylogenetic tree based on nearly-complete 16S rRNA gene sequences showing the relationships between strain $\mathrm{IP}-10^{\top}$ and a selection of species of the genus Flavobacterium. The tree was constructed by the neighbour-joining method and rooted by using Cellulophaga lytica ATCC $23178^{\top}$ as an outgroup. Numbers at nodes represent bootstrap percentages (based on 100 resamplings; only values $>50 \%$ are shown). Bar, 0.05 substitutions per nucleotide position. 
(comprising $\mathrm{C}_{16: 1} \omega 7 c$ and/or iso- $\mathrm{C}_{15: 0} 2-\mathrm{OH} ; 13.2 \%$ ). A predominance of iso- $\mathrm{C}_{15: 0}$ and iso- $\mathrm{C}_{17: 0} 3-\mathrm{OH}$ is found in most members of the family Flavobacteriaceae. Overall, the FAME profile of strain IP- $10^{\mathrm{T}}$ matched that of other members of the genus Flavobacterium (Bernardet et al., 1996; Bernardet \& Bowman, 2006), but minor differences in the respective proportions of some components might have resulted from the different growth conditions used.

Growth of strain IP- $10^{\mathrm{T}}$ was tested on nutrient agar, LuriaBertani agar, TSA, Anacker and Ordal's agar (Anacker \& Ordal, 1955) and MacConkey agar. As strain IP- $10^{\mathrm{T}}$ showed luxuriant growth on TSA and in the corresponding broth (TSB) at $37^{\circ} \mathrm{C}$, most phenotypic tests were performed at this temperature. Gram and spore staining were performed by using HiMedia's Gram and spore staining kits, respectively. Colony morphology (shape, size, colour and pigmentation) was studied on TSA after $72 \mathrm{~h}$ incubation at $37^{\circ} \mathrm{C}$. For observation of cell morphology, a suspension of strain IP- $10^{\mathrm{T}}$ was placed on a carbon-coated copper grid, negatively stained with uranyl acetate $(0.5 \%)$ and observed by using a transmission electron microscope (model 269D; Morgagni). Gliding motility was investigated by using phase-contrast microscopy of a hanging-drop preparation from a TSB culture (Bernardet et al., 2002). Growth at different $\mathrm{pH}$ and salt concentrations was tested in TSB adjusted to $\mathrm{pH} 4,5,6,7,7.5,8,9$ and 10 with $1.0 \mathrm{M}$ $\mathrm{HCl}$ or $1.0 \mathrm{M} \mathrm{NaOH}$ or supplemented with $1,2,3,4$ or $5 \%$ (w/v) $\mathrm{NaCl}$ as described by Arden-Jones et al. (1979). Growth in TSB was also tested at $10,25,37$ and $40{ }^{\circ} \mathrm{C}$. Antibiotic resistance was tested on Muller-Hinton agar by using commercial discs (HiMedia); plates were incubated at $37{ }^{\circ} \mathrm{C}$ for $72 \mathrm{~h}$. Catalase and oxidase production was tested as described by McCarthy \& Cross (1984). Tests for hydrolysis of casein, gelatin, starch, tyrosine, aesculin and Tween 80 were performed as described by Cowan \& Steel (1965). Hydrolysis of chitin, pectin and carboxymethylcellulose was tested on Czapek-Dox agar $\left(2 \mathrm{~g} \mathrm{NaNO}_{3}, 1 \mathrm{~g}\right.$ $\mathrm{K}_{2} \mathrm{HPHO}_{4}, 0.5 \mathrm{~g} \mathrm{MgSO}_{4}, 0.5 \mathrm{~g} \mathrm{KCl}, 0.01 \mathrm{~g} \mathrm{FeSO}_{4}$ and $15 \mathrm{~g}$ agar per litre) containing $0.5 \%(\mathrm{w} / \mathrm{v})$ of each substrate. Urease activity was tested according to Christensen (1946). Tests for the production of indole, the reduction of nitrate and the Voges-Proskauer reaction were performed according to Smibert \& Krieg (1994). Production of $\mathrm{H}_{2} \mathrm{~S}$ was tested on stabs of triple-sugar iron agar (15 g peptone, $5 \mathrm{~g}$ proteose-peptone, $3 \mathrm{~g}$ beef extract, $3 \mathrm{~g}$ yeast extract, $1 \mathrm{~g}$ lactose, $1 \mathrm{~g}$ sucrose, $1 \mathrm{~g}$ glucose, $5 \mathrm{~g} \mathrm{NaCl}, 0.2 \mathrm{~g} \mathrm{FeSO}_{4}$, $0.3 \mathrm{~g} \mathrm{Na}_{2} \mathrm{~S}_{2} \mathrm{O}_{3}, 0.024 \mathrm{~g}$ phenol red and $12 \mathrm{~g}$ agar per litre). Production of a precipitate on egg yolk was tested on TSA containing $30 \%$ egg yolk emulsion (HiMedia). Production of $\beta$-galactosidase was determined by using commercial discs (HiMedia) following the manufacturer's instructions. DNase activity was tested by using DNase agar (HiMedia) supplemented with $0.005 \%$ methyl green. The presence of flexirubin-type pigments and Congo red absorption were determined according to Reichenbach (1992) and Bernardet et al. (2002). Utilization of glucose, sucrose and lactose was tested as described by Hugh \& Leifson
(1953) under aerobic as well as anaerobic conditions (created by overlaying sterile liquid paraffin). Importantly, this medium contained peptone $(0.2 \%)$ in which anaerobic growth of some members of the genus Flavobacteria has been reported (Bernardet \& Bowman, 2006). The ability to degrade $\mathrm{HCH}$ was tested according to Sharma et al. (2006). The $G+C$ content of the genomic DNA was determined as described by Gonzalez \& Saiz-Jimenez (2002) by using an Applied Biosystems 7500 real-time PCR at the Department of Zoology, University of Delhi, India.

The morphological, physiological and biochemical features of strain IP- $10^{\mathrm{T}}$ are given in the species description below, in Table 1 and in Fig. 2. Although allocated to the genus Flavobacterium based on $16 \mathrm{~S}$ rRNA gene sequence data, strain IP- $10^{\mathrm{T}}$ could be differentiated from all related species of the genus Flavobacterium based on a number of phenotypic characteristics (Table 1). DNA-DNA hybridization experiments were not performed as 16S rRNA gene sequence similarity with other strains was well below the recommended limit of $97 \%$ (Wayne et al., 1987). Strain

Table 1. Differential phenotypic characteristics between strain $\mathrm{IP}-10^{\top}$ and phylogenetically related species of the genus Flavobacterium

Strains: 1, IP- $10^{\mathrm{T}} ; 2$, F. terrae DSM $18829^{\mathrm{T}}$ (data from Weon et al., 2007); 3, F. cucumis DSM $18830^{\mathrm{T}}$ (Weon et al., 2007); 4, F. aquatile DSM $1132^{\mathrm{T}} ; 5$, F. columnare LMG $13035^{\mathrm{T}}$ (Bernardet et al., 1996); 6, F. croceum EMB47 ${ }^{\mathrm{T}}$ (Park et al., 2006); 7, F. indicum DSM $17447^{\mathrm{T}}$ (Saha \& Chakrabarti, 2006); 8, F. saliperosum JCM $13331^{\mathrm{T}}$ (Wang et al., 2006); 9, F. suncheonense KACC $11423^{\mathrm{T}}$ (Kim et al., 2006). +, Positive; - , negative; $(+)$, weakly positive; ++ , strongly positive; $\mathrm{v}$, variable among the data sources; ND, data not available.

\begin{tabular}{|c|c|c|c|c|c|c|c|c|c|}
\hline Characteristic & 1 & 2 & 3 & 4 & 5 & 6 & 7 & 8 & 9 \\
\hline \multicolumn{10}{|l|}{ Growth on: } \\
\hline Nutrient agar & + & + & + & - & - & - & $(+)$ & + & + \\
\hline TSA & ++ & $(+)$ & $(+)$ & + & - & $(+)$ & - & + & $(+)$ \\
\hline Gliding motility & + & - & + & + & + & - & - & - & - \\
\hline \multicolumn{10}{|l|}{ Production of: } \\
\hline Oxidase & - & + & + & + & + & + & + & - & + \\
\hline Catalase & + & - & + & + & + & - & $(+)$ & + & + \\
\hline $\begin{array}{l}\text { Flexirubin-type } \\
\text { pigment }\end{array}$ & - & + & - & - & + & - & - & + & - \\
\hline Nitrate reductase & - & - & - & $\mathrm{V}$ & $\mathrm{V}$ & - & - & - & - \\
\hline$\beta$-Galactosidase & - & - & - & + & - & $\mathrm{ND}$ & $\mathrm{ND}$ & $\mathrm{ND}$ & - \\
\hline \multicolumn{10}{|l|}{ Hydrolysis of: } \\
\hline Aesculin & + & - & + & $\mathrm{v}$ & - & - & - & - & - \\
\hline Gelatin & - & + & + & V & + & + & + & + & + \\
\hline Starch & - & + & + & V & - & - & + & - & - \\
\hline Tyrosine & - & - & + & V & - & - & - & + & + \\
\hline $\begin{array}{l}\text { Absorption of } \\
\text { Congo red }\end{array}$ & - & - & - & - & + & - & - & - & - \\
\hline $\begin{array}{l}\text { DNA G }+\mathrm{C} \\
\text { content }(\mathrm{mol} \%)\end{array}$ & 31 & 34 & 38 & 33 & 32 & 41 & 31 & 41 & 39 \\
\hline
\end{tabular}



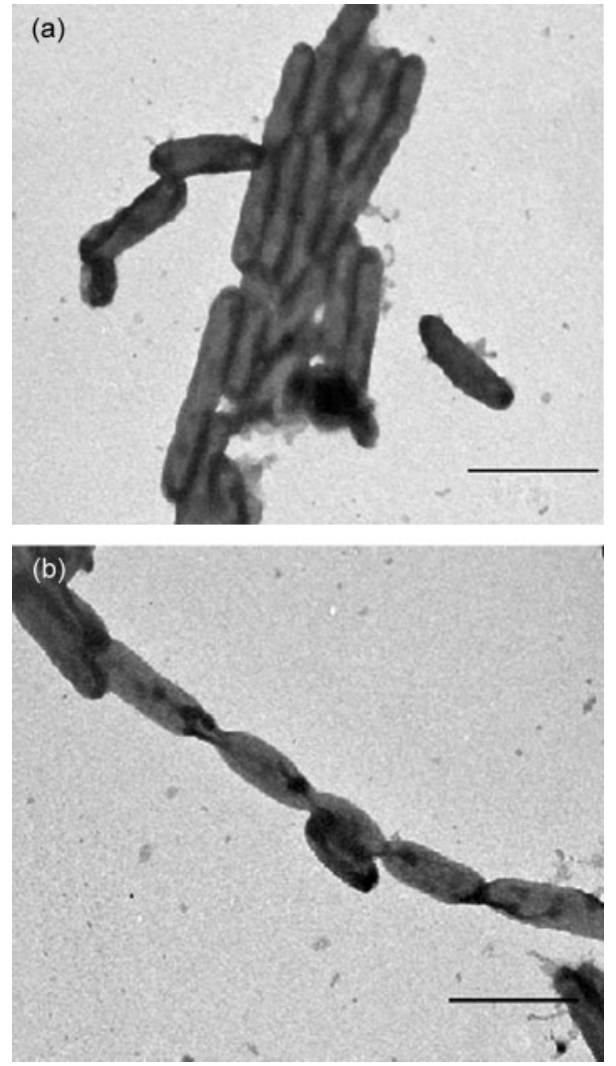

Fig. 2. Transmission electron micrographs of negatively stained cells of strain IP-10 $10^{\top}$ showing a group of parallel rods (a) and a chain of rods (b). Bars, $2 \mu \mathrm{m}$.

IP- $10^{\mathrm{T}}$ is thus considered to represent a novel species of the genus Flavobacterium, for which the name Flavobacterium lindanitolerans sp. nov. is proposed.

\section{Description of Flavobacterium lindanitolerans sp. nov.}

Flavobacterium lindanitolerans (lin.da.ni.to.le' rans. N.L. n. lindanum lindane; L. part. adj. tolerans tolerating; N.L. part. adj. lindanitolerans lindane-tolerating).

Cells are Gram-negative, non-sporulating, aerobic, nonflagellated rods that are motile by gliding, $0.5 \mu \mathrm{m}$ in diameter and $1.8 \mu \mathrm{m}$ in length, occurring singly, in groups of parallel cells or in short chains. Predominantly aerobic. Weak anaerobic growth occurs in peptone-containing media. Growth occurs on Luria-Bertani, nutrient, Anacker and Ordal's and MacConkey agars. Colonies on TSA are flat, cream-yellow with entire margins and $3.5 \mathrm{~mm}$ in diameter after $72 \mathrm{~h}$ incubation. Growth occurs at $10-37{ }^{\circ} \mathrm{C}$ (optimum, $37^{\circ} \mathrm{C}$ ), at $\mathrm{pH}$ 6-9 (optimum, 7.5) and in the presence of $1-2 \% \mathrm{NaCl}$ (optimum, $1 \%$ ). Catalase activity is present, but oxidase, urease and nitrate reductase activities are absent. Aesculin is hydrolysed, but gelatin, casein, DNA, starch, carboxymethylcellulose, pectin, chitin, tyrosine and Tween 80 are not. Although isolated from a highly $\mathrm{HCH}$-contaminated environment, the organism is unable to degrade $\mathrm{HCH}$. Congo red is not absorbed by the colonies. Flexirubin-type pigments are not produced ( $\mathrm{KOH}$ test-negative). No pigment is produced on tyrosine agar. Indole and $\mathrm{H}_{2} \mathrm{~S}$ are not produced. No precipitate is formed on egg yolk agar. Methyl red and Voges-Proskauer reactions are negative. No acid is produced from glucose, sucrose or lactose. Sensitive to nalidixic acid $(30 \mu \mathrm{g})$, tetracycline $(30 \mu \mathrm{g})$, vancomycin $(30 \mu \mathrm{g})$, amoxicillin $(10 \mu \mathrm{g})$, penicillin $(10 \mu \mathrm{g})$, neomycin $(30 \mu \mathrm{g})$, novobiocin $(30 \mu \mathrm{g})$, chlortetracycline $(30 \mu \mathrm{g})$ and neomycin $(30 \mu \mathrm{g})$, but resistant to streptomycin $(10 \mu \mathrm{g})$, kanamycin $(30 \mu \mathrm{g})$, chloramphenicol $(30 \mu \mathrm{g})$, rifamycin $(5 \mu \mathrm{g})$, erythromycin $(15 \mu \mathrm{g})$, ampicillin $(10 \mu \mathrm{g})$ and gentamicin $(10 \mu \mathrm{g})$. Major fatty acids are $\mathrm{C}_{15: 0}(22.1 \%)$, iso- $\mathrm{C}_{17: 0} 3-\mathrm{OH}(18.5 \%)$, summed feature 3 (comprising iso- $\mathrm{C}_{15: 0} 2-\mathrm{OH}$ and/or $\mathrm{C}_{16: 1} \omega 7 c ; 13.2 \%$ ), iso- $\mathrm{C}_{15: 0} 3-\mathrm{OH}$ $(8.8 \%)$, iso- $\mathrm{C}_{15: 1} \mathrm{G}(6.7 \%)$, iso- $\mathrm{C}_{16: 0}(5.2 \%), \mathrm{C}_{18: 0}$ $(4.6 \%), \mathrm{C}_{15.0} 3-\mathrm{OH}(3.5 \%), \mathrm{C}_{15.0} 2-\mathrm{OH}(3.1 \%)$, iso$\mathrm{C}_{16: 0} 3-\mathrm{OH}(2.3 \%)$, iso- $\mathrm{C}_{17: 1} \omega 9 c(1.7 \%), \mathrm{C}_{17: 0} 3-\mathrm{OH}$ $(1.2 \%)$ and anteiso- $\mathrm{C}_{15: 0}(1.1 \%)$. Traces $(<1 \%)$ of the following fatty acids are also present: iso- $\mathrm{C}_{17: 0}, \mathrm{C}_{17: 1} \omega 6 \mathrm{c}$ and $\mathrm{C}_{18: 1} \omega 9 c$. The $\mathrm{G}+\mathrm{C}$ content of the genomic DNA as determined by real-time PCR is $31 \mathrm{~mol} \%$.

The type strain, IP- $10^{\mathrm{T}}\left(=\right.$ MTCC $\left.8597^{\mathrm{T}}=\mathrm{CCM} 7424^{\mathrm{T}}\right)$, was isolated from soil that was highly contaminated by $\mathrm{HCH}$ from a waste site at Ummari village, Lucknow city, Uttar Pradesh, India.

\section{Acknowledgements}

This work was supported by grants from the Department of Biotechnology (DBT) and National Bureau of Agriculturally Important Microorganisms (NBAIM, ICAR), Government of India. S. J., M.D. and O.P. gratefully acknowledge the Council of Scientific and Industrial Research (CSIR), and NBAIM, ICAR, Government of India, for providing the research fellowship. We also thank SAIF-DST (Sophisticated Analytical Instrumentation Facility, Department of Science and Technology, Department of Anatomy, AIIMS) for providing the transmission electron microscopy facility. We would like to thank J. P. Euzéby (Ecole Nationale Vétérinaire, Toulouse, France) for etymological advice.

\section{References}

Anacker, R. L. \& Ordal, E. J. (1955). Study of a bacteriophage infecting the myxobacterium Chondrococcus columnaris. J Bacteriol 70, 738-741.

Arden-Jones, M. P., McCarthy, A. J. \& Cross, T. (1979). Taxonomic and serological studies on Micropolyspora faeni and Micropolyspora strains from soil bearing the specific epithet rectivirgula. J Gen Microbiol 115, 343-354.

Bergey, D. H., Harrison, F. C., Breed, R. S., Hammer, B. W. \& Huntoon, F. M. (1923). Genus II. Flavobacterium gen. nov. In Bergey's Manual of Determinative Bacteriology, pp. 97-117. Baltimore: Williams \& Wilkins. 
Bernardet, J.-F. \& Bowman, J. (2006). The genus Flavobacterium. In The Prokaryotes: A Handbook on the Biology of Bacteria, 3rd edn, vol. 7, pp. 481-531. Edited by M. Dworkin, S. Falkow, E. Rosenberg, K. H. Schleifer \& E. Stackebrandt. New York: Springer.

Bernardet, J. F., Segers, P., Vancanneyt, M., Berthe, F., Kersters, K. \& Vandamme, P. (1996). Cutting a Gordian knot: emended classification and description of the genus Flavobacterium, emended description of the family Flavobacteriaceae, and proposal of Flavobacterium hydatis nom. nov. (basonym, Cytophaga aquatilis Strohl and Tait 1978). Int J Syst Bacteriol 46, 128-148.

Bernardet, J.-F., Nakagawa, Y. \& Holmes, B. (2002). Proposed minimal standards for describing new taxa of the family Flavobacteriaceae and emended description of the family. Int J Syst Evol Microbiol 52, 1049-1070.

Christensen, W. B. (1946). Urea decomposition as a means of differentiating Proteus and Paracolon cultures from each other and from Salmonella and Shigella types. J Bacteriol 52, 461-466.

Chun, J., Lee, J.-H., Jung, Y., Kim, M., Kim, S., Kim, B. K. \& Lim, Y. W. (2007). EzTaxon: a web-based tool for the identification of prokaryotes based on $16 \mathrm{~S}$ ribosomal RNA gene sequences. Int J Syst Evol Microbiol 57, 2259-2261.

Cowan, S. T. \& Steel, K. J. (1965). Manual for the Identification of Medical Bacteria. London: Cambridge University Press.

Felsenstein, J. (1993). PHYLIP (phylogeny inference package), version 3.5c. Department of Genome Sciences, University of Washington, Seattle, USA.

Gonzalez, J. M. \& Saiz-Jimenez, C. (2002). A fluorimetric method for the estimation of $\mathrm{G}+\mathrm{C}$ mol\% content in microorganisms by thermal denaturation temperature. Environ Microbiol 4, 770-773.

Hugh, R. \& Leifson, E. (1953). The taxonomic significance of fermentative versus oxidative metabolism of carbohydrates by various gram negative bacteria. J Bacteriol 66, 24-26.

Humphry, D. R., George, A., Black, G. W. \& Cummings, S. P. (2001). Flavobacterium frigidarium sp. nov., an aerobic, psychrophilic, xylanolytic and laminarinolytic bacterium from Antarctica. Int J Syst Evol Microbiol 51, 1235-1243.

Jukes, T. H. \& Cantor, C. R. (1969). Evolution of protein molecules. In Mammalian Protein Metabolism, pp. 21-132. Edited by H. N. Munro. New York: Academic Press.

Kim, B. Y., Weon, H. Y., Cousin, S., Yoo, S. H., Kwon, S. W., Go, S. J. \& Stackebrandt, E. (2006). Flavobacterium daejeonense sp. nov. and Flavobacterium suncheonense sp. nov., isolated from greenhouse soils in Korea. Int J Syst Evol Microbiol 56, 1645-1649.

Kuykendall, L. D., Roy, M. A., O'Neill, J. J. \& Devine, T. E. (1988). Fatty acids, antibiotic resistance, and deoxyribonucleic acid homology groups of Bradyrhizobium japonicum. Int J Syst Bacteriol 38, 358-361.

McCarthy, A. J. \& Cross, T. (1984). A taxonomic study of Thermomonospora and other monosporic actinomycetes. J Gen Microbiol 130, 5-25.

Miller, L. T. (1982). Single derivatization method for the routine analysis of whole-cell fatty acid methyl esters, including hydroxyl acids. J Clin Microbiol 16, 584-586.

Park, M., Lu, S., Ryu, S. H., Chung, B. S., Park, W., Kim, C.-J. \& Jeon, C. O. (2006). Flavobacterium croceum sp. nov., isolated from activated sludge. Int J Syst Evol Microbiol 56, 2443-2447.

Prakash, O., Kumari, K. \& Lal, R. (2007). Pseudomonas delhiensis sp. nov., from a fly ash dumping site of a thermal power plant. Int J Syst Evol Microbiol 57, 527-531.
Reichenbach, H. (1992). The order Cytophagales. In The Prokaryotes. A Handbook on the Biology of Bacteria: Ecophysiology, Isolation, Identification, Applications, 2nd edn, pp. 3631-3675. Edited by A. Balows, H. G. Trüper, M. Dworkin, W. Harder \& K. H. Schleifer. New York: Springer.

Saha, P. \& Chakrabarti, T. (2006). Flavobacterium indicum sp. nov., isolated from warm spring water in Assam, India. Int J Syst Evol Microbiol 56, 2617-2621.

Saitou, N. \& Nei, M. (1987). The neighbor-joining method: a new method for reconstructing phylogenetic trees. Mol Biol Evol 4, 406-425.

Sharma, P., Raina, V., Kumari, R., Malhotra, S., Dogra, C., Kumari, H., Kohler, H. P., Buser, H. R., Holliger, C. \& Lal, R. (2006). The haloalkane dehalogenase LinB is responsible for $\beta$ - and $\delta$-hexachlorocyclohexane transformation in Sphingobium indicum B90A. Appl Environ Microbiol 72, 5720-5727.

Smibert, R. M. \& Krieg, N. R. (1994). Phenotypic characterization. In Methods for General and Molecular Bacteriology, pp. 607-654. Edited by P. Gerhardt, R. G. E. Murray, W. A. Wood \& N. R. Krieg. Washington, DC: American Society for Microbiology.

Thompson, J. D., Gibson, T. J., Plewniak, F., Jeanmougin, F. \& Higgins, D. G. (1997). The CLUSTAL_X windows interface: flexible strategies for multiple sequence alignment aided by quality analysis tools. Nucleic Acids Res 25, 4876-4882.

Van de Peer, Y. \& De Wachter, R. (1994). TREECON for Windows: a software package for the construction and drawing of evolutionary trees for the Microsoft Windows environment. Comput Appl Biosci 10, 569-570.

Van Trappen, S., Mergaert, J. \& Swings, J. (2003). Flavobacterium gelidilacus sp. nov., isolated from microbial mats in Antarctic lakes. Int J Syst Evol Microbiol 53, 1241-1245.

Van Trappen, S., Vandecandelaere, I., Mergaert, J. \& Swings, J. (2004). Flavobacterium degerlachei sp. nov., Flavobacterium frigoris sp. nov. and Flavobacterium micromati sp. nov., novel psychrophilic bacteria isolated from microbial mats in Antarctic lakes. Int J Syst Evol Microbiol 54, 85-92.

Vanbroekhoven, K., Ryngaert, A., Bastiaens, L., Wattiau, P., Vancanneyt, M., Swings, J., Mot, R. D. \& Springael, D. (2004). Streptomycin as a selective agent to facilitate recovery and isolation of introduced and indigenous sphingomonas from environmental samples. Environ Microbiol 6, 1123-1136.

Wang, Z. W., Liu, Y. H., Dai, X., Wang, B. J., Jiang, C. Y. \& Liu, S. J. (2006). Flavobacterium saliperosum sp. nov., isolated from freshwater lake sediment. Int J Syst Evol Microbiol 56, 439-442.

Wayne, L. G., Brenner, D. J., Colwell, R. R., Grimont, P. A. D., Kandler, O., Krichevsky, M. I., Moore, L. H., Moore, W. E. C., Murray, R. G. E. \& other authors (1987). International Committee on Systematic Bacteriology. Report of the ad hoc committee on reconciliation of approaches to bacterial systematics. Int J Syst Bacteriol 37, 463-464.

Weon, H. Y., Song, M. H., Son, J. A., Kim, B. Y., Kwon, S. W., Go, S. J. \& Stackebrandt, E. (2007). Flavobacterium terrae sp. nov. and Flavobacterium cucumis sp. nov., isolated from greenhouse soil. Int J Syst Evol Microbiol 57, 1594-1598.

Woese, C. R., Mandelco, L., Yang, D., Gherna, R. \& Madigan, M. T. (1990). The case for relationship of the Flavobacteria and their relatives to the green sulfur bacteria. Syst Appl Microbiol 13, 258-262.

Yoon, J.-H., Kang, S.-J. \& Oh, T.-K. (2006). Flavobacterium soli sp. nov., isolated from soil. Int J Syst Evol Microbiol 56, 997-1000. 